Communication

\title{
First Record of the Nudibranch Tenellia adspersa (Nordmann, 1845) in Portugal, Associated with the Invasive Hydrozoan Cordylophora caspia (Pallas, 1771)
}

\author{
João Encarnação *®D, Thomas Seyer, Maria Alexandra Teodósio ${ }^{\mathbb{D}}$ and Francisco Leitão $\mathbb{D}$ \\ CCMAR-Centre of Marine Sciences, University of Algarve, Campus de Gambelas, 8005-139 Faro, Portugal; \\ thomas.seyer@hotmail.fr (T.S.); mchichar@ualg.pt (M.A.T.); fleitao@ualg.pt (F.L.) \\ * Correspondence: jpencarnacao@ualg.pt
}

Received: 13 May 2020; Accepted: 26 May 2020; Published: 28 May 2020

check for updates

\begin{abstract}
The estuarine nudibranch Tenellia adspersa (Nordmann, 1845) was recorded for the first time in Portugal, while sampling for fouling fauna of artificial structures along the salinity gradient of the Guadiana estuary (SW Iberian Peninsula). Two specimens were found in association with the invasive hydrozoan Cordylophora caspia (Pallas, 1771) and kept in the laboratory for taxonomy purposes. After two days, batches of eggs were seen in C. caspia branches, while the nudibranchs were also actively feeding on the hydrozoan polyps. The fast generation times of $T$. adspersa, along with its food preference for $C$. caspia, might suggest a positive role of the nudibranch on controlling this invasive hydrozoan in the Guadiana estuary. Introduction routes and facilitation interactions are discussed.
\end{abstract}

Keywords: Heterobranchia; nudibranch; sea slug; Tenellia; Portugal; estuarine; facilitation; invasive species; biological control

\section{Introduction}

Nudibranchs, the most diverse group of sea slugs (Gastropoda: Heterobranchia), are a widely distributed and diverse group of molluscs, found at their highest diversity in marine shallow coastal areas, with fewer associated with estuarine and brackish habitats [1,2]. The cosmopolitan aeolid Tenellia adspersa (Nordmann, 1845), along with the recently described Bohuslania matsmichaeli (Korshunova, Lundin, Malmberg, Picton and Martynov, 2018), are widely recognized as the only nudibranchs associated with brackish-water habitats [2-4].

The study species, T. adspersa, although considered a cosmopolitan species nowadays, the historical records point out to an European origin, with the first description of the species being made in the Black Sea, followed by other records in the Baltic Sea, North-West Iberian Peninsula and the British Isles [5-7]. Past misidentifications and nomenclature changes undermine present-day access to information on the distribution of T. adspersa, as several synonyms existed, namely Embletonia grayi Kent, 1869, Embletonia pallida Alder and Hancock, 1854, Eolis armoricana Hesse, 1872, Eolis ventilabrum Dalyell, 1853, Tenellia mediterranea Costa A., 1866, Tenellia pallida (Alder and Hancock, 1845) or Tergipes adspersus Nordmann, 1845. The available literature using some of these synonyms, confirms its cosmopolitan distribution across the North-East Atlantic Ocean and Mediterranean Sea [8,9]. Still, only a few recent records across Europe have been published, namely in the Baltic Sea [4] or the Mediterranean Sea [10]. Available records in online databases such as GBIF [11] or OBIS [12] show scattered records across the coasts of Finland, Sweden, Germany, Netherlands, the United Kingdom and Spain. In other parts of the world, such as North America [13-15] or India [16], it is considered a non-indigenous species. 
In the Iberian Peninsula, according to the latest checklist on 'opisthobranchs' made in 2004 for Spain and Portugal, including islands and archipelagos, only three records were identified for T. adspersa, all in mainland Spain [17]. The oldest record is on the Atlantic coast in Galicia, namely inside 'Ría do Ferrol', found on the hydrozoan Ectopleura larynx, on the hull of a shipwreck [6]. A second record of eight individuals was made in the Mediterranean coast of Spain inside 'Mar Menor', feeding on the hydrozoans Obelia dichotoma and Pachycordyle pusilla [18]. These specimens were initially identified as T. pallida, a synonym of T. adspersa. A more recent record dates from 2001 on the Atlantic coast, in Sancti-Petri, close to the city of Cadiz (SW Iberian Peninsula) (unpublished record, see Cervera et al. 2004; GBIF occurrence ID 31777043). The present study aims at describing the first record of T. adspersa in Portugal, including additional information on development stages and remarks on its association with the invasive hydrozoan Cordylophora caspia (Pallas, 1771).

\section{Materials and Methods}

\subsection{Study Area}

Sampling took place during the summer of 2016 in the Guadiana estuary, located in SE Portugal/SW Spain (Figure 1). The tidal influence on this mesotidal estuary extends to Mértola (Station 7, Figure 1), $70 \mathrm{~km}$ away from the coast, while the river flow varies substantially among and within years, as is characteristic of regions with a Mediterranean climate, with the additional regularization by the Alqueva dam, located $180 \mathrm{~km}$ from the river mouth [19]. As in other regions with Mediterranean climate, the rainfall regime in the area is very irregular between years, with $80 \%$ concentrated in autumn and winter, while summers are very dry [19]. The estuary can be divided into three areas (Figure 1): the upper estuary, with salinity close to zero ( $<0.5 \mathrm{PSU})$, the middle estuary, characterized as the mixing zone of brackish water (0.5-25 PSU), and the lower estuary, with salinity closer to seawater ( $>25$ PSU) [20]. The mixing zone of the middle estuary, where sampling took place (Figure 1), is also one of the zones with higher fluctuations in environmental variables. At Station 2, annual values of surface water temperature can change between 9 and $27^{\circ} \mathrm{C}$, while salinity ranges between 0 and 15 PSU, all changing according to tidal influence and seasonal river flow [21].

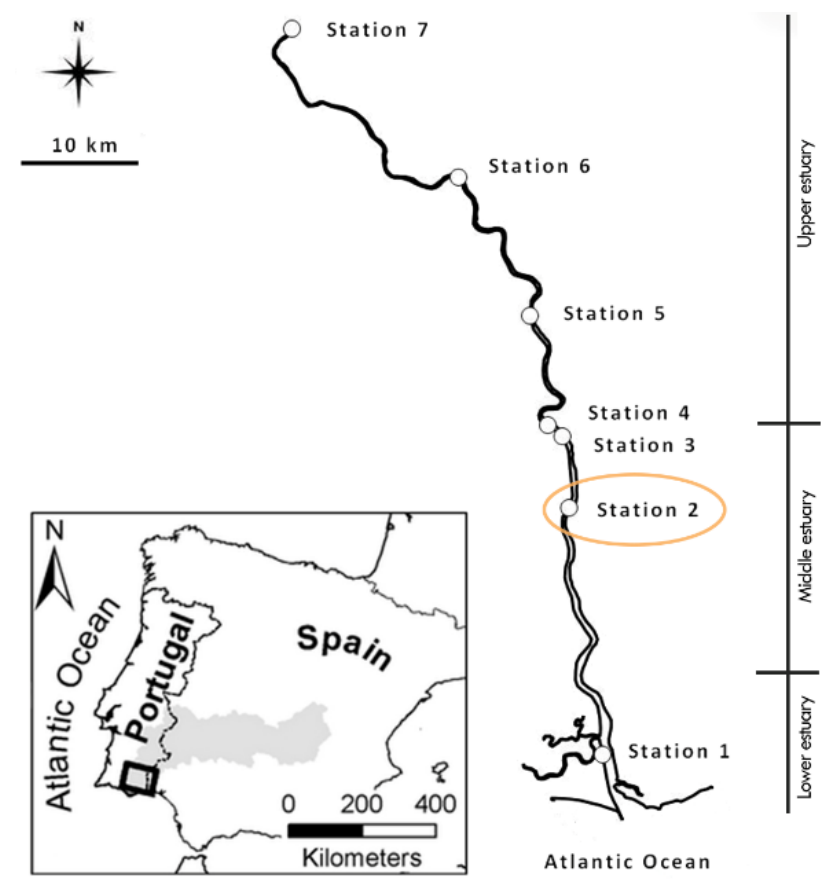

Figure 1. Location of the Guadiana estuary in SW Iberian Peninsula and all the seven sampling stations. Station 2, where Tenellia adspersa was found, is highlighted. Adapted from Seyer et al. (2017). 


\subsection{Sampling Methods}

Sampling took place along a salinity gradient that was intended to characterize fouling fauna of artificial structures, namely hydrozoans [22]. Visual inspection and sampling of floating artificial structures, such as pontoons, in each sampling station resulted in many samples being retrieved to the laboratory. For detailed sampling methods, see Seyer et al., 2017. During live sorting, two nudibranchs from a sample collected on 26 July 2016 at Station 2 (GPS: 37.353544; -7.440794) were separated in an individual container for further identification, as they constituted unusual fauna for the study area. Specimens were kept in saltwater with some branches of the hydrozoan C. caspia, as they were originally found in the Guadiana estuary. On subsequent days of observation, the specimens laid several batches of eggs, which led us to document the process over the following weeks. Nevertheless, the experimental conditions were not entirely controlled, as the initial purpose was purely species identification.

\section{Results}

The two specimens retrieved at Station 2 were identified as Tenellia adspersa (Nordmann, 1845) (Figure 2) according to several diagnostic features, such as the round oral veil and the arrangement of the cerata in four to six groups, each with one to three elongated, cylindrical and semi-transparent cerata $[5,7,8,23]$. The sampling station number 2 , located in the middle estuary (Figure 1), was characterized by a salinity value of 13.8 and a water temperature of $27.1^{\circ} \mathrm{C}$, measured at the surface in the day of sampling (Table 1).

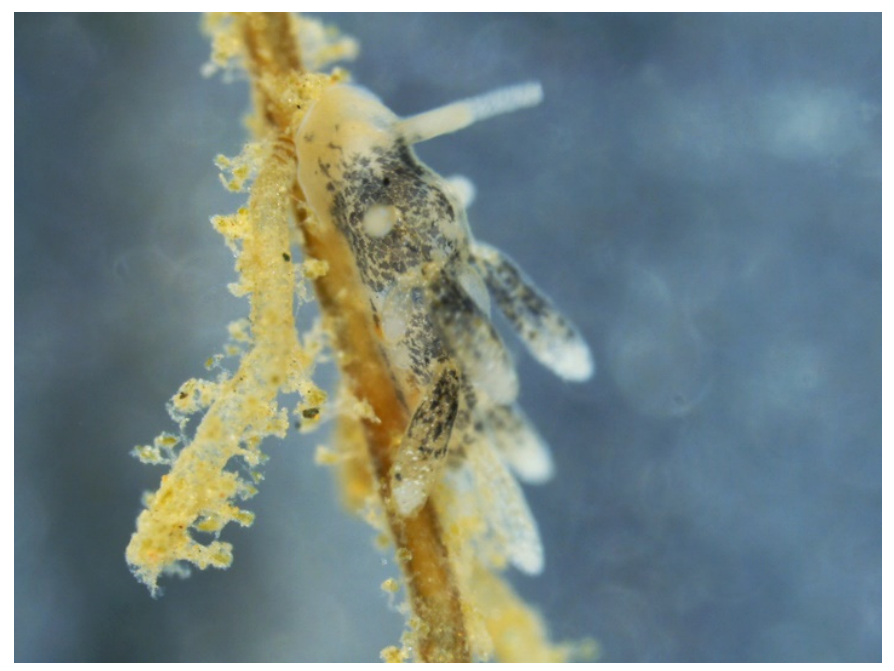

Figure 2. One of the adults of Tenellia adspersa collected in the Guadiana estuary on 26 July 2016.

Table 1. Salinity and temperature measurements along the seven sampling stations in the Guadiana estuary on 26 July 2016.

\begin{tabular}{cccccccc}
\hline Station & $\mathbf{1}$ & $\mathbf{2}$ & $\mathbf{3}$ & $\mathbf{4}$ & $\mathbf{5}$ & $\mathbf{6}$ & $\mathbf{7}$ \\
\hline Salinity & 34.0 & 13.8 & 4.9 & 3.3 & 0.3 & 0.2 & 0.1 \\
Temperature $\left({ }^{\circ} \mathrm{C}\right)$ & 25.1 & 27.1 & 28.0 & 27.9 & 28.4 & 28.8 & 31.7 \\
\hline
\end{tabular}

* Indicates the sampling station where Tenellia adspersa was found.

After 2 days at the laboratory, several batches of eggs were found in C. caspia branches (Figure 3A). Eggs developed (Figure 3B) and metamorphic individuals were observed inside egg masses after 5-7 days (Figure 3C). Hatching occurred after 9-12 days from collection in the Guadiana estuary (Figure 3D) and juveniles were observed in subsequent days (Figure 3E). After 2-3 weeks, the number of egg masses was increasingly higher, mostly due to the new generation reaching maturity and starting to spawn. 

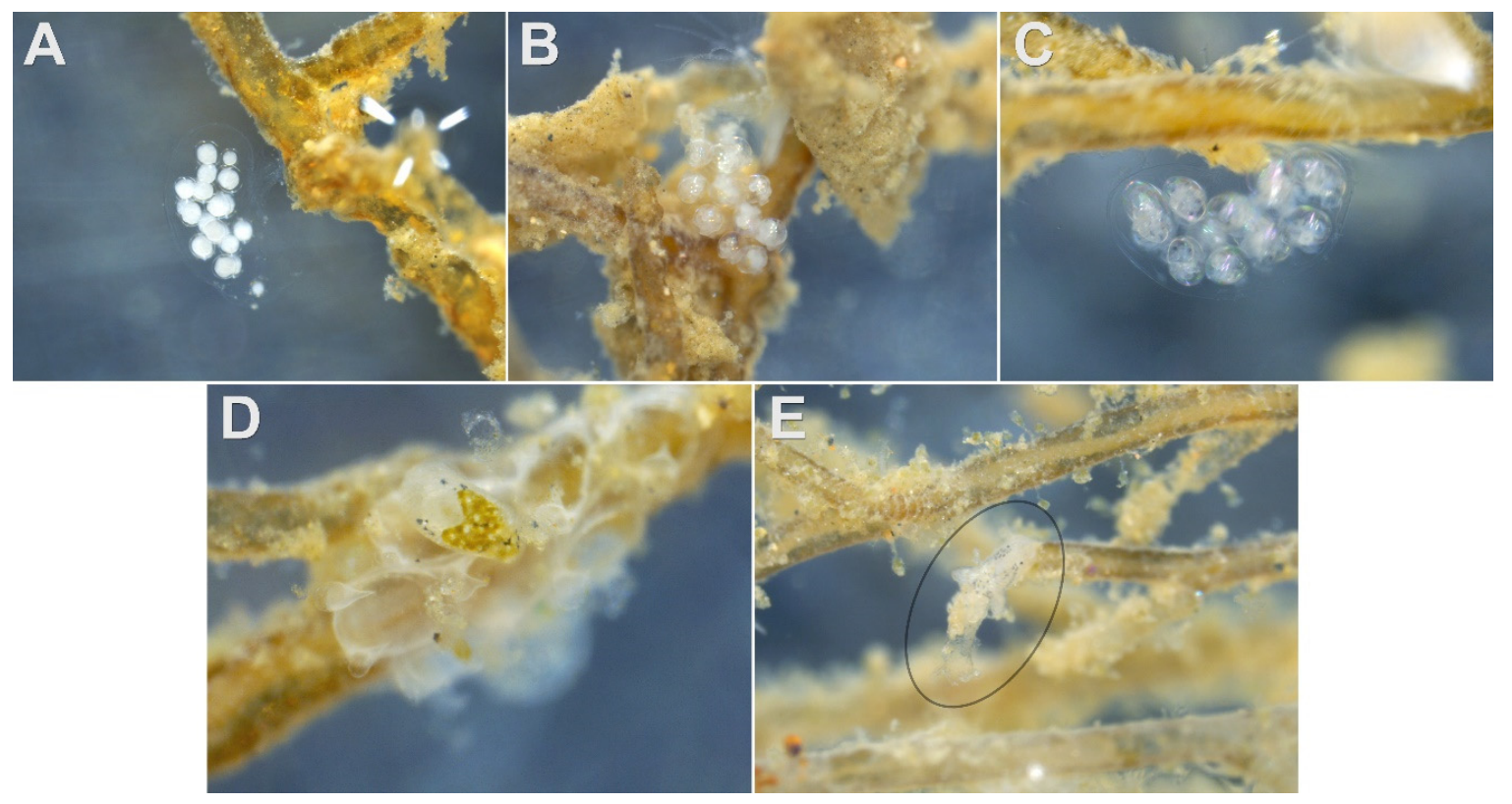

Figure 3. The several stages of development of Tellenia adspersa documented in laboratory. (A) Batch of eggs after 2 days at laboratory; (B) intermediate phase of development; (C) metamorphic individuals inside eggs; (D) juveniles after hatching; (E) a juvenile days after hatching.

\section{Discussion}

Considering the available literature, this record of T. adspersa in the Guadiana estuary is the first known occurrence of this species in Portugal. The habitat where it was found, the brackish-water zone of an estuary, coincides with other literature describing it as a tolerant species in terms of salinity, with an apparent optimum in the range between 12 and 25 [3,24], although it is found in the Baltic Sea at salinities of 6 PSU [4]. The reproductive biology of T. adspersa also makes it a very adaptable species, namely its fast generation times and reaching sexual maturity within 2 to 3 weeks after hatching $[3,23]$. Two different reproductive modes may also be used by the same population, the first where batches of small eggs produce pelagic free-swimming veliger larvae, and a second mode where batches of fewer, larger eggs produce capsular metamorphic individuals [23]. This capacity may also increase the survival and adaptability of T. adspersa, as the pelagic free-swimming larvae disperse over larger areas, while the metamorphic larvae will hatch as well-developed juveniles, increasing the chances of survival [23].

The origin of this species is difficult to pin-point, although several hypotheses can be explored. Shipping and ballast-water have always been major drivers of species dissemination across distant geographical areas, as also suggested for the presence of T. adspersa in North America [14] or India [16]. This vector of introduction can either bring a species from thousands of kilometres across an entire ocean, or from a neighbouring country just a few hundreds of kilometres away. Looking at the past known distribution of T. adspersa, the closest known record was in Cadiz, just ca. $150 \mathrm{~km}$ from the Guadiana estuary [17], or in the NW Iberian Peninsula in Galicia, ca. $690 \mathrm{~km}$ away [6]. Therefore, individuals from the Gulf of Cadiz may have naturally reached the Guadiana estuary, as there are some coastal lagoon systems in between, or aided by human-mediated vectors of introduction.

The habitat where the specimens were found also suggests possible explanations on the presence of the species in the Guadiana estuary, or rather why it was recorded now and not before on other recurrent sampling campaigns. The specimens were found on C. caspia hydrozoans and in laboratory were observed feeding actively on their polyps. The presence of the invasive hydrozoan C. caspia in the Guadiana estuary at least since 2015 [22] may have a facilitative effect on the native nudibranch. Facilitation processes by invasive species on native species have already been documented worldwide, and may range from habitat modification or creation, trophic subsidy, or food source diversification 
and nutrient enrichment [25]. Studies made on predation by T. adspersa on Cordylophora lacustris, nowadays considered a synonym of $C$. caspia, indicated a preference for this prey upon other hydroids such as Obelia commiseralis or Hydractinia echinata [3,24]. Several other authors also recorded this food preference, namely in Finland [4] or North America [15].

Fouling organisms such as C. caspia can create a variety of economic problems related to water intakes, namely by blocking tubes, filters, irrigation systems or reducing flow in water cooling systems [26-28]. Although thermal and chemical treatments with chloride have been shown to effectively control C. caspia, these pose several economic and environmental challenges [26,29]. Biological control of invasive species as long been a subject of intense debate, namely on the unpredictable effects on non-target species [30]. Nevertheless, this control does not have to be through the deliberate introduction of new species. Control of invasive species by predation of native species may go unnoticed, and is generally neglected in the literature, but several examples have been documented. In the British Isles, the sacoglossan nudibranchs Placida dendritica and Elysia viridis showed, in some cases, a preference for an invasive Codium macroalgae over other native congeners [31]. In North America, in Chesapeake Bay, a natural control by the native blue crab Callinectes sapidus on young invasive rapa whelk Rapana venosa was documented [32]. In Europe, the use of the European eel Anguilla anguilla as an indigenous predator was proposed and tested towards the invasive red swamp crayfish Procambarus clarkii, while also contributing to the conservation efforts of the already threatened native European eel [33].

Our observations are in fact the first documentation of a potential predator for the invasive C. caspia in the Guadiana estuary, already impacted by several other invasive species [22,34-37]. Regarding the presence of C. caspia in the Guadiana estuary, it was first detected in June 2015, and in 2016 was recorded in five sampling stations across a $25 \mathrm{~km}$ stretch along the Guadiana estuary, on salinities between 0.2 and 13.8 [22]. The availability of hard substrate along this brackish area of the estuary, represented by artificial structures or mooring pontoons, also created a suitable habitat for C. caspia, which then created a suitable habitat for the nudibranch T. adspersa. Therefore, the discovery of the T. adspersa nudibranch in the Guadiana estuary in June 2016 is most likely the result of a facilitation process that may have occurred not only regarding food availability but also by an increase in habitat availability. The fast generation times of T. adspersa of about 17 days from egg to egg reported by Chester [3], which was consistent with what we observed at the laboratory, and food preference for C. caspia, suggest that it might play an important role in controlling the dispersal of the invasive hydrozoan, which must also be further investigated in future sampling campaigns and prey selection experiments.

Author Contributions: Conceptualization and investigation, J.E., M.A.T. and F.L.; Field work, T.S., M.A.T. and F.L.; writing — original draft preparation, J.E.; writing - review and editing, J.E., T.S., M.A.T. and F.L. All authors have read and agreed to the published version of the manuscript.

Funding: J.E. has a Ph.D. scholarship (SFRH/BD/140556/2018) funded by the Foundation for Science and Technology (FCT, Portugal). M.A.T. was funded by Foundation for Science and Technology (FCT, Portugal) through the Jellyfisheries project (PTDC/MAR-BIO/0440/2014) and the project UID/04326/2020, and by the European Regional Development Fund (COMPETE - Operational Competitiveness Programme). F.L. received Portuguese national funds from FCT contract program DL57/2016/CP1361/CT0008.

Acknowledgments: We would like to acknowledge the additional confirmation on the species identification and current status in Portugal given by the experts. Gonçalo Calado and underwater photographer João Pedro Silva. We also thank the two anonymous reviewers for their valuable contributions towards improving this manuscript.

Conflicts of Interest: The authors declare no conflict of interest.

\section{References}

1. García, F.J.; Bertsch, H. Diversity and distribution of the Gastropoda Opisthobranchia from the Atlantic Ocean: A global biogeographic approach. Sci. Mar. 2009, 73, 153-160. [CrossRef]

2. Korshunova, T.; Lundin, K.; Malmberg, K.; Picton, B.; Martynov, A. First true brackish-water nudibranch mollusc provides new insights for phylogeny and biogeography and reveals paedomorphosis-driven evolution. PLOS ONE 2018, 13, e0192177. [CrossRef] 
3. Chester, C.M. The effect of adult nutrition on the reproduction and development of the estuarine nudibranch, Tenellia adspersa (Nordmann, 1845). J. Exp. Mar. Biol. Ecol. 1996, 198, 113-130. [CrossRef]

4. Evertsen, J.; Bakken, T.; Green, S. Rediscovery of Tenellia adspersa (Nudibranchia) from the Finnish archipelago. Sarsia 2004, 89, 362-365. [CrossRef]

5. Roginskaya, I. Tenellia adspersa, a nudibranch new to the Azov Sea, with notes on its taxonomy and ecology. Malac. Rev. 1970, 3, 167-174.

6. Urgorri, V.; Besteiro, C. Inventario de los moluscos Opistobranquios de Galicia. Investig. Pesq. 1983, 47, 3-28.

7. Thompson, T.E.; Brown, G.H. Biology of Opisthobranch Molluscs; The Ray Society: London, UK, 1984; Volume 2, p. 280.

8. Schmekel, L.; Portmann, A. Opisthobranchia des Mittelmeeres; Springer: Berlin, Germany, 1982; p. 410.

9. Platts, E. An annotated list of the North Atlantic Opisthobranchia (excluding Thecosomata and Gymnosomata). Ophelia Suppl. 1985, 2, 150-170.

10. Zenetos, A.; Mačić, V.; Jaklin, A.; Lipej, L.; Poursanidis, D.; Cattaneo-Vietti, R.; Beqiraj, S.; Betti, F.; Poloniato, D.; Kashta, L. Adriatic 'opisthobranchs' (Gastropoda, Heterobranchia): Shedding light on biodiversity issues. Mar. Ecol. 2016, 37, 1239-1255. [CrossRef]

11. GBIF. Tenellia Adspersa (Nordmann, 1845). Available online: https://gbif.org/species/2292354 (accessed on 21 April 2020).

12. OBIS. Tenellia Adspersa (Nordmann, 1845). Available online: https://obis.org/taxon/141639 (accessed on 21 April 2020).

13. Cohen, A.N.; Carlton, J.T. Nonindigenous Aquatic Species in a United States Estuary: A Case Study of the Biological Invasions of the San Francisco Bay and Delta; Report No. PB96-166525; National Technical Information Service: Alexandria, VA, USA, 1995; p. 292.

14. Wasson, K.; Zabin, C.J.; Bedinger, L.; Diaz, M.C.; Pearse, J.S. Biological invasions of estuaries without international shipping: The importance of intraregional transport. Biol. Conserv. 2001, 102, 143-153. [CrossRef]

15. Meek, M.H.; Wintzer, A.P.; Wetzel, W.C.; May, B. Climate change likely to facilitate the invasion of the non-native hydroid, Cordylophora caspia, in the San Francisco estuary. PLoS ONE 2012, 7, e46373. [CrossRef]

16. Dhanya, A.; Jeyabaskaran, R.; Prema, D.; Chinnadurai, S.; Sajikumar, K.; Kripa, V. Non-indigenous sea slug Tenellia adspersa in the southeast coast of the Arabian Sea, India. Curr. Sci. 2017, 113, 24-26.

17. Cervera, J.L.; Calado, G.; Gavaia, C.; Malaquias, M.; Templado, J.; Ballesteros, M.; Gómez, J.C.G.; Martínez, C.M. An annotated and updated checklist of the opisthobranchs (Mollusca: Gastropoda) from Spain and Portugal (including islands and archipelagos). Boletin-Instituto Español de Oceanografia 2004, 20, $1-122$.

18. Marín, A.; Ros, J. Catálogo preliminar de los gasterópodos marinos del sudeste español. Iberus 1987, 7, 137-145.

19. Morais, P. Review on the major ecosystem impacts caused by damming and watershed development in an Iberian basin (SW-Europe): Focus on the Guadiana estuary. Ann. Limnol.-Int. J. Lim. 2008, 44, 105-117. [CrossRef]

20. Chícharo, L.; Hamadou, R.B.; Amaral, A.; Range, P.; Mateus, C.; Piló, D.; Marques, R.; Morais, P.; Chícharo, M.A. Application and demonstration of the Ecohydrology approach for the sustainable functioning of the Guadiana estuary (South Portugal). Ecohydrol. Hydrobiol. 2009, 9, 55-71. [CrossRef]

21. Domingues, R.B.; Galvao, H. Phytoplankton and environmental variability in a dam regulated temperate estuary. Hydrobiologia 2007, 586, 117-134. [CrossRef]

22. Seyer, T.; Morais, P.; Amorim, K.; Leitão, F.; Martins, F.; Teodósio, M.A. On the presence of the Ponto-Caspian hydrozoan Cordylophora caspia (Pallas, 1771) in an Iberian estuary: Highlights on the introduction vectors and invasion routes. BioInvasions Rec. 2017, 6, 331-337. [CrossRef]

23. Eyster, L. Reproduction and developmental variability in the opisthobranch Tenellia pallida. Mar. Biol. 1979, 51, 133-140. [CrossRef]

24. Blezard, D.J. Salinity as a Refuge from Predation in a Nudibranch-Hydroid Relationship within the Great Bay Estuary System. Master's Thesis, University of New Hampshire, Durham, NH, USA, May 1999. Available online: http://citeseerx.ist.psu.edu/viewdoc/download?doi=10.1.1.570.6121\&rep=rep1\&type=pdf (accessed on 13 May 2020).

25. Rodriguez, L.F. Can invasive species facilitate native species? Evidence of how, when, and why these impacts occur. Biol. Invasions 2006, 8, 927-939. [CrossRef] 
26. Folino-Rorem, N.C.; Indelicato, J. Controlling biofouling caused by the colonial hydroid Cordylophora caspia. Water Res. 2005, 39, 2731-2737. [CrossRef] [PubMed]

27. Wood, T. The pipeline menace of freshwater bryozoans. Denisia 16; Kataloge der Oberosterreichischen Landesmuseen 2005, 28, 203-208.

28. Mant, R.; Moggridge, G.; Aldridge, D. Biofouling by bryozoans, Cordylophora and sponges in UK water treatment works. Water Sci. Technol. 2011, 63, 1815-1822. [CrossRef] [PubMed]

29. Rajagopal, S.; Van der Velde, G.; Van der Gaag, M.; Jenner, H. Laboratory evaluation of the toxicity of chlorine to the fouling hydroid Cordylophora caspia. Biofouling 2002, 18, 57-64. [CrossRef]

30. Messing, R.H.; Wright, M.G. Biological control of invasive species: Solution or pollution? Front. Ecol. Environ. 2006, 4, 132-140. [CrossRef]

31. Trowbridge, C.D. Emerging associations on marine rocky shores: Specialist herbivores on introduced macroalgae. J. Anim. Ecol. 2004, 73, 294-308. [CrossRef]

32. Harding, J.M. Predation by blue crabs, Callinectes sapidus, on rapa whelks, Rapana venosa: Possible natural controls for an invasive species? J. Exp. Mar. Biol. Ecol. 2003, 297, 161-177. [CrossRef]

33. Aquiloni, L.; Brusconi, S.; Cecchinelli, E.; Tricarico, E.; Mazza, G.; Paglianti, A.; Gherardi, F. Biological control of invasive populations of crayfish: The European eel (Anguilla anguilla) as a predator of Procambarus clarkii. Biol. Invasions 2010, 12, 3817-3824. [CrossRef]

34. Morais, P.; Teodósio, J.; Reis, J.; Teodósio, M.A.; Chícharo, L. The Asian clam Corbicula fluminea (Müller, 1774) in the Guadiana River Basin (southwestern Iberian Peninsula): Setting the record straight. Aquat. Invasions 2009, 4, 681-684. [CrossRef]

35. Teodósio, M.A.; Leitão, T.; Range, P.; Gutierrez, C.; Morales, J.; Morais, P.; Chícharo, L. Alien species in the Guadiana Estuary (SE-Portugal/SW-Spain): Blackfordia virginica (Cnidaria, Hydrozoa) and Palaemon macrodactylus (Crustacea, Decapoda): Potential impacts and mitigation measures. Aquat. Invasions 2009, 4, 501-506.

36. Morais, P.; Teodósio, M.A. The transatlantic introduction of weakfish Cynoscion regalis (Bloch \& Schneider, 1801) (Sciaenidae, Pisces) into Europe. BioInvasions Rec. 2016, 5, 259-265.

37. Morais, P.; Gaspar, M.; Garel, E.; Baptista, V.; Cruz, J.; Cerveira, I.; Leitão, F.; Teodósio, M.A. The Atlantic blue crab Callinectes sapidus Rathbun, 1896 expands its non-native distribution into the Ria Formosa lagoon and the Guadiana estuary (SW-Iberian Peninsula, Europe). BioInvasions Rec. 2019, 8, 123-133. [CrossRef] 